\title{
Post-treatment of secondary wastewater treatment plant effluent using a two-stage fluidized bed bioreactor system
}

\author{
Golam Hossein Safari ${ }^{1 \dagger}$, Kaan Yetilmezsoy ${ }^{2 \dagger}$, Amir Hossein Mahvi ${ }^{3}$ and Mansur Zarrabi $i^{4^{*}+}$
}

\begin{abstract}
The aim of this study was to investigate the performance of a two-stage fluidized bed reactor (FBR) system for the post-treatment of secondary wastewater treatment plant effluents (Shahrak Gharb, Tehran, Iran). The proposed treatment scheme was evaluated using pilot-scale reactors (106-L of capacity) filled with PVC as the fluidized bed (first stage) and gravel for the filtration purpose (second stage). Aluminum sulfate (30 mg/L) and chlorine (1 mg/L) were used for the coagulation and disinfection of the effluent, respectively. To monitor the performance of the FBR system, variation of several parameters (biochemical oxygen demand $\left(\mathrm{BOD}_{5}\right)$, chemical oxygen demand (COD), turbidity, total phosphorous, total coliform and fecal coliform) were monitored in the effluent wastewater samples. The results showed that the proposed system could effectively reduce $\mathrm{BOD}_{5}$ and $\mathrm{COD}$ below 1.95 and $4.06 \mathrm{mg} / \mathrm{L}$, respectively. Turbidity of the effluent could be achieved below 0.75 NTU, which was lower than those reported for the disinfection purpose. The total phosphorus was reduced to $0.52 \mathrm{mg} / \mathrm{L}$, which was near the present phosphorous standard for the prevention of eutrophication process. Depending on both microorganism concentration and applied surface loading rates $(5-10 \mathrm{~m} / \mathrm{h}$ ), about 35 to $75 \%$ and 67 to $97 \%$ of coliform were removed without and with the chlorine addition, respectively. Findings of this study clearly confirmed the efficiency of the FBR system for the post-treatment of the secondary wastewater treatment plant effluents without any solid problem during the chlorination.
\end{abstract}

Keywords: Secondary effluent, COD, Coliform, Fluidized bed reactor

\section{Introduction}

Application of fluidized bed reactors (FBR) in wastewater treatment has received much attention in the world today due to their high efficiency, and low capital and operating costs. This technology is also gaining popularity as a result of increasingly stringent discharge standards and increased water reclamation demand. In recent years, FBR technology has also been conducted as an effective method to treat various types of high-strength wastewaters such as corn steep liquor [1], distillery effluent [2], synthetic sago wastewater [3], high-sulfate wastewater [4] and so on.

\footnotetext{
* Correspondence: mansor62@gmail.com

${ }^{\dagger}$ Equal contributors

${ }^{4}$ Department of Environmental Health Engineering, Faculty of Health, Alborz University of Medical Sciences, Karaj, Iran

Full list of author information is available at the end of the article
}

In general, effluents from secondary wastewater treatment plants are further treated in tertiary plants for reuse. In tertiary treatment plants, various methods such as membrane processes, advanced oxidation process, adsorption, filtration and others can be used for purification or post-treatment of wastewater effluents $[5,6]$. The properties of wastewater effluents can directly influence the filtration rate and selection of the appropriate filter media. In water treatment plants, filter media are often selected as sand matter and fixed in a tank [7]. In filtration of secondary wastewater treatment plant effluents for the future reuse, the filter media sizes are often lighter and greater for prevention from clothing, as well as for providing higher operation time. However, in that case, the filter media may not be able to properly treat the effluents due to greater filter media size [8]. If the filter media is chosen as fine as possible, the clothing and lower operation time will become the main problems. 
To overcome these problems, a proper alternative can be the treatment of effluents before passing through the filter media [7]. Considering the above-mentioned facts, it is noteworthy that FBR technology can be used as an effective method for the complete biological treatment of the secondary wastewater effluents before the filtration process.

To the best of the authors' knowledge, there are no systematic papers in the literature specifically devoted to a study regarding the application of a two-stage FBR system with a filtration column for treatment of secondary effluents. Therefore, clarification of the place of the present subject in the scheme of secondary wastewater treatment can be considered as a specific field of investigation to compare results with the above-mentioned studies. For that reason, the aim of the present work was to investigate the performance of a two-stage fluidized bed bioreactor system, filled with PVC as the fluidized bed (first stage) and gravel for the filtration purpose (second stage), for the post-treatment of the secondary wastewater treatment plant effluent.

\section{Materials and methods}

\section{Wastewater sample}

The raw wastewater samples were obtained from Shahrak Gharb (Tehran, Iran) wastewater treatment plant effluents. The type of treatment in Shahrak Gharb wastewater treatment plant was activated sludge with surface aerator. Some wastewater characteristics of the samples are given in Table 1. Components of the obtained samples were determined by the procedures described in the Standard Methods [9].

\begin{tabular}{|c|c|c|c|c|}
\hline Parameters & Minimum & Maximum & Average & $S D^{a}$ \\
\hline $\begin{array}{l}\text { 5-day Biochemical Oxygen } \\
\text { Demand }\left(\mathrm{BOD}_{5}, \mathrm{mg} / \mathrm{L}\right)\end{array}$ & 16.9 & 21.5 & 18.76 & 1.78 \\
\hline $\begin{array}{l}\text { Chemical Oxygen Demand } \\
(C O D, \mathrm{mg} / \mathrm{L})\end{array}$ & 32 & 40 & 35.38 & 3.61 \\
\hline $\begin{array}{l}\text { Total Kjeldahl Nitrogen } \\
\text { (TKN, mg/L) }\end{array}$ & 0.69 & 2.76 & 1.69 & 0.797 \\
\hline Total Phosphorus (TP, mg/L) & 4.5 & 4.9 & 4.75 & 0.16 \\
\hline Total Solids (TS, mg/L) & 556 & 704.6 & 640.72 & 64.18 \\
\hline Turbidity (NTU) & 6.2 & 7.5 & 6.86 & 0.559 \\
\hline $\begin{array}{l}\text { Electrical Conductivity } \\
(E C, \mu \mathrm{moss} / \mathrm{cm})\end{array}$ & 730 & 935 & 833 & 81.06 \\
\hline Total Coliform (MPN/100 mL) & $22 \times 10^{3}$ & $175 \times 10^{3}$ & 115800 & 61650 \\
\hline Fecal Coliform (MPN/100 mL) & $14 \times 10^{3}$ & $105 \times 10^{3}$ & 58280 & 37420 \\
\hline $\mathrm{pH}$ & 7.2 & 7.5 & 7.32 & 0.13 \\
\hline
\end{tabular}

\section{Preparation of bacterial culture}

Multiple tube fermentation method was used for determination of total coliform and also fecal coliform. The Lactose broth, Brilliant Green and EC broth (Merck, Germany) were used for the preparation of the microbial culture. Microbial culture was prepared according to the procedures described in the Standard Methods [9].

\section{Bioreactor set-up}

A simple schematic of the present bioreactor is depicted in Figure 1. As seen in Figure 1, the FBR system has two cylindrical columns. The first column was filled with PVC material $(0.40 \mathrm{~m}$ in height) with an effective size of $4 \mathrm{~mm}$ and $0.84 \mathrm{~g} / \mathrm{cm}^{3}$ density. About $40 \%$ of the first column was filled with PVC matter for better fluidization of the bed. The second column was filled with gravel $(0.50 \mathrm{~m}$ in height) with an effective size of $2 \mathrm{~mm}$ and $2.5 \mathrm{~g} / \mathrm{cm}^{3}$ density for the final clarification. The gravels were obtained from the local area. Prior to filling the second bed, the gravels were kept in $10 \% \mathrm{HCl}$ solution to remove any clay and other residual contaminants. The external diameter, total height and total capacity of both columns were $30 \mathrm{~cm}, 150 \mathrm{~cm}$ and $106 \mathrm{~L}$, respectively. All parts of the reactors were made of transparent Plexiglas material with a wall thickness of $2 \mathrm{~mm}$. The effluents were pumped by peristaltic pumps (Masterflex Cole-Parmer Vernon Hills, IL, USA) at surface loading rates of 5.0, 7.5 and 10.0 $\mathrm{m} / \mathrm{h}$. The range of surface loading rates was chosen based on filter media size and target pollutant [10-12]. The FBR system was designed to maintain $2 \mathrm{~cm}$ of wastewater column above both beds to ensure a continuous flow rate. Perforated diffuser plates (with $1 \mathrm{~mm}$-hole diameter) were used at the above and bottom of the beds.

On the basis of the preliminary jar test results, aluminum sulfate $(30 \mathrm{mg} / \mathrm{L})$ was added into secondary effluents for the coagulation purpose. Chlorine $(1 \mathrm{mg} / \mathrm{L})$ was added for the disinfection of the effluents. The wastewater samples were mixed with a vertical stirrer (Lovibond, USA) to obtain a uniform environment in feeding material. The FBR system was operated in a continuous mode feeding by pumping of the fresh feed into the reactors. The bioreactors were maintained at respective temperatures for about 10 days to allow temperature equilibration and the growth of microorganisms. After this period, the performance of the present FBR system was investigated in a temperaturecontrolled environment $\left(35^{\circ} \mathrm{C}\right)$ by collecting wastewater samples from the effluent of the second bed at predetermined intervals of $2 \mathrm{~h}$ for the further microbial and physicochemical analyses.

\section{Pressure drop and washing of beds}

The pressure drop was determined as a measure of decrease in flow rate and removal efficiency. The height of 


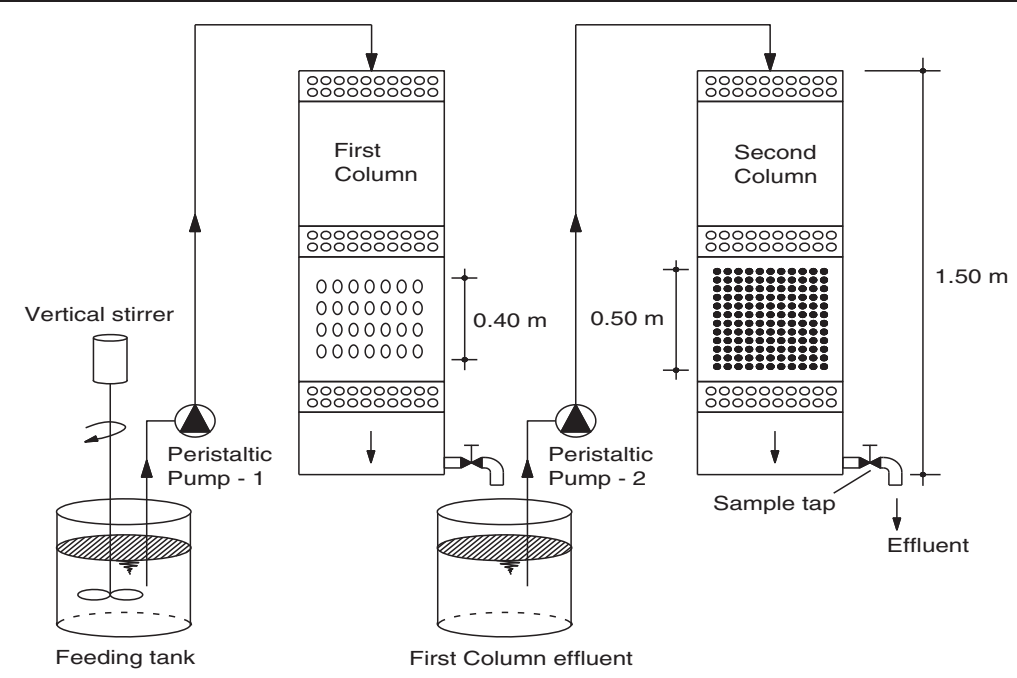

Figure 1 Schematic of the experimental set-up.

the water column above of both columns was maintained as $2 \mathrm{~cm}$ to ensure continuous flow rate and to avoid channeling of the wastewater. When the height of the water column reached to about $2.2 \mathrm{~cm}$, the columns were removed and backwashed with the distilled water. Moreover, when the pollutant concentration in bioreactor effluents exceeded the influent concentration, the bioreactor was cleaned by backwashing. In the present work, both methods were applied to investigate the pressure drop problem. The second column was backwashed once per two days of operation to prevent pressure drop. During backwashing of the second bed, the effluent from the first column was re-circulated towards the inlet of the first bed to maintain the microbial activity. For the present case, it was observed that most of the sludge was captured at the internal parts of the second bed.

\section{Results and discussion}

\section{Removal of $\mathrm{BOD}_{5}$ and $\mathrm{COD}$}

The concentration of biological oxygen demand $\left(\mathrm{BOD}_{5}\right)$ in wastewater treatment plant effluents can significantly influence the dissolved oxygen rate in receiving water bodies. The daily standard for $\mathrm{BOD}_{5}$ in secondary wastewater effluents is limited to be maintained at or below $30 \mathrm{mg} / \mathrm{L}$ by authorized organization $[7,13]$. In addition, the concentration of $\mathrm{BOD}_{5}$ in clean water or clean rivers is restricted to as low as $2 \mathrm{mg} / \mathrm{L}$ [14]. Therefore, any treatment methods must reduce the $\mathrm{BOD}_{5}$ concentration to below $2 \mathrm{mg} / \mathrm{L}$.

Figure 2a shows the removal of $\mathrm{BOD}_{5}$ at different surface loading rates. It is clear from this figure that $\mathrm{BOD}_{5}$ and surface loading rate significantly influence the removal efficiency. Higher removal efficiency was observed in $7.5 \mathrm{~m} / \mathrm{h}$ surface rate and $18.5 \mathrm{mg} / \mathrm{L}$ of $\mathrm{BOD}_{5}$ concentration. In this condition, about $91 \%$ of $\mathrm{BOD}_{5}$ was
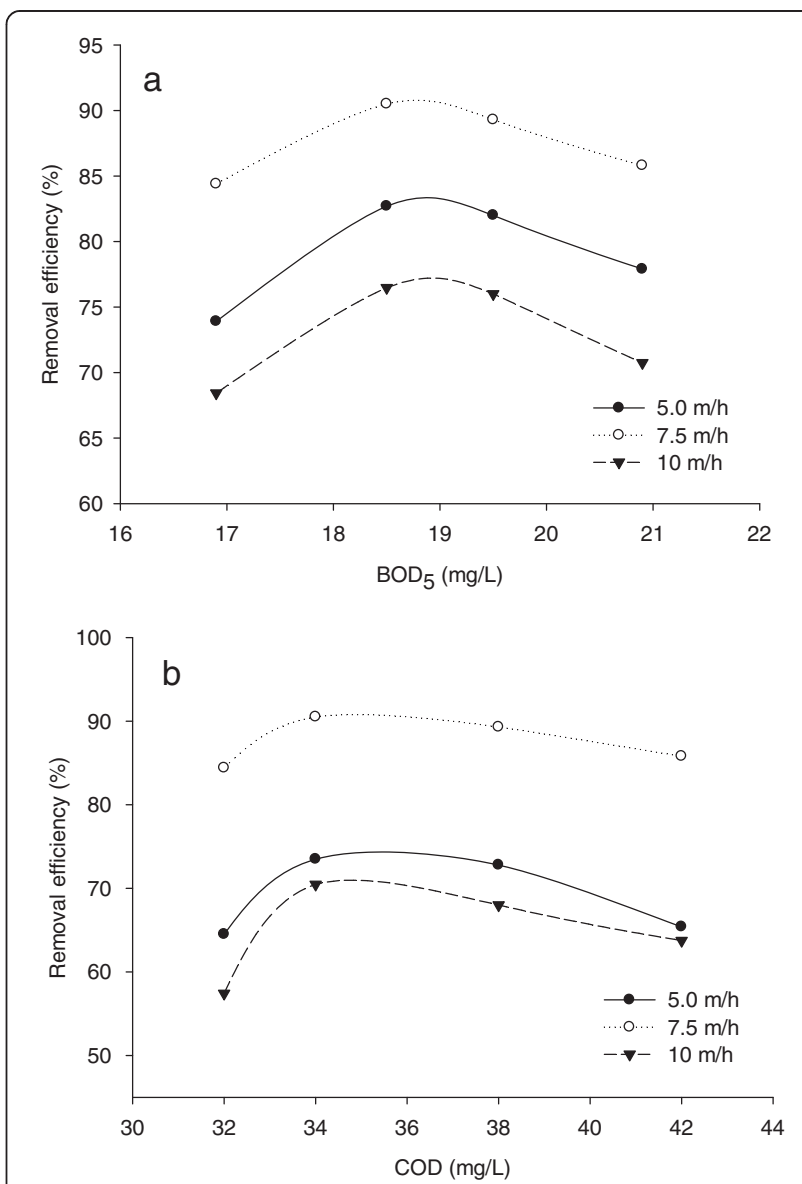

Figure 2 Removal efficiency of $\mathrm{BOD}_{5}(\mathrm{a})$ and $\mathrm{COD}(\mathrm{b})$ at different initial concentrations and surface loading rates. 
removed and the $\mathrm{BOD}_{5}$ concentration in the FBR effluent was observed to be $1.67 \mathrm{mg} / \mathrm{L}$. In addition, at that surface rate and the initial $\mathrm{BOD}_{5}$ concentration of $19.5 \mathrm{mg} / \mathrm{L}$, the effluent concentration was measured to be about $1.95 \mathrm{mg} / \mathrm{L}$. Therefore, it can be concluded that the present system can meet the available standards at $7.5 \mathrm{~m} / \mathrm{h}$ of hydraulic rate and the initial $\mathrm{BOD}_{5}$ concentration of 18.5 to $19.5 \mathrm{mg} / \mathrm{L}$. The lowest removal efficiency was observed at $20.9 \mathrm{mg} / \mathrm{L}$ of $\mathrm{BOD}_{5}$ and $10 \mathrm{~m} / \mathrm{h}$ of hydraulic rate. In this condition, the final concentration of $\mathrm{BOD}_{5}$ was determined as $6.11 \mathrm{mg} / \mathrm{L}$.

Figure $2 \mathrm{~b}$ illustrates the removal of COD at different surface loading rates. Likewise, higher removal efficiency for COD was observed at $7.5 \mathrm{~m} / \mathrm{h}$ of surface loading rate and initial COD concentration of $34 \mathrm{mg} / \mathrm{L}$. At this condition, about $90.05 \%$ of COD was removed and the effluent concentration was reduced to about $3.23 \mathrm{mg} / \mathrm{L}$. For the initial COD concentration of $38 \mathrm{mg} / \mathrm{L}$ and at $7.5 \mathrm{~m} / \mathrm{h}$ of surface loading rate, the effluent concentration of COD was reached to be $4.06 \mathrm{mg} / \mathrm{L}$. Furthermore, the lower removal efficiency was observed at $10 \mathrm{~m} / \mathrm{h}$ hydraulic rate. Based on the relationship between $\mathrm{BOD}_{5}$ and $\mathrm{COD}$ $[7,9]$, the present system can reduce the influent COD concentration to below available standards at initial COD concentration of 34 to $38 \mathrm{mg} / \mathrm{L}$ and at $7.5 \mathrm{~m} / \mathrm{h}$ of hydraulic rate.

In the tertiary treatment (coagulation-flocculationdisinfection for irrigation reuse) of a secondary wastewater treatment plant effluent, removal percentages for $\mathrm{BOD}_{5}$ and $\mathrm{COD}$ (initial $\mathrm{BOD}_{5}$ and COD concentrations were $11.6( \pm 3.1) \mathrm{mg} / \mathrm{L}$ and $38.8( \pm 6.3) \mathrm{mg} / \mathrm{L}$, respectively) was obtained to be $46 \%$ and $39 \%$, respectively. In the study, the authors reported that the final $\mathrm{BOD}_{5}$ and COD concentrations were reached to $6.3( \pm 2.4) \mathrm{mg} / \mathrm{L}$ and $25.4( \pm 4.8) \mathrm{mg} / \mathrm{L}$, respectively [15]. In another work [16], slow sand filtration system was conducted for the post-treatment of up-flow anaerobic sludge blanket (UASB) reactor effluent (average $\mathrm{BOD}_{5}$ and $\mathrm{COD}$ was about 50 and $120 \mathrm{mg} / \mathrm{L}$, respectively). The study concluded that removal percentages for $\mathrm{BOD}_{5}$ and $\mathrm{COD}$ were achieved to be $43 \%$ and $34 \%$ in during the first few hours $(36 \mathrm{~h})$ and reached to be about $85 \%$ and $79 \%$ after 7 days operation, respectively. Therefore, after 7 days operation, the $\mathrm{BOD}_{5}$ and $\mathrm{COD}$ concentrations in slow sand filter effluent were observed to be 7.5 and $25.2 \mathrm{mg} / \mathrm{L}$, respectively [16]. With respect to slow sand filtration and coagulation-flocculation-disinfection process, results obtained from the present work was remarkable since the final concentrations of $\mathrm{BOD}_{5}$ and $\mathrm{COD}$ were 1.67 and $3.23 \mathrm{mg} / \mathrm{L}$, respectively, which were much lower than those works.

\section{Removal of turbidity}

Removal of turbidity is necessary for an effective disinfection process. In the water environment, the turbidity agent can protect the viral and bacterial organism against the disinfectant matter. For an effective disinfection, the authorized organization have been set up the turbidity standard as low as 1 NTU. In addition, the turbidity can be used as a measure of filter performance and pressure drop $[17,18]$. For that reason, in this work, removal of turbidity was investigated as an important wastewater characteristic. Figure 3 shows the removal of turbidity at various turbidity unit and surface loading rate. The highest removal efficiency was observed at 5 $\mathrm{m} / \mathrm{h}$ surface loading rate and 7.26 unit of turbidity. At this condition, about $89.67 \%$ of turbidity was removed and therefore final value reached to below 0.75 NTU. As mentioned earlier, for an effective disinfection, turbidity must be lower than $1 \mathrm{NTU}$. Therefore, the present FBR system is capable to reduce turbidity to below 1 NTU.

Considering the higher percentage removal of turbidity (89.67\%) and lower turbidity in the effluent, it can be concluded that the results obtained in the present work was better than the values reported in post treatment of UASB reactor effluent by slow sand filtration [16]. In that work, the average turbidity was 56.5 NTU and the maximum removal percentage was reported to be $91.60 \%$. Based on this removal efficiency, the turbidity in effluent was reached to an average of 2.9 NTU. In that work, the sand depth and effective size was $54 \mathrm{~cm}$ and $0.43 \mathrm{~mm}$, respectively. As compared to that work, however higher initial turbidity, the present system containing a fluidized bed with a filter medium with $50 \mathrm{~cm}$ gravel depths and $2 \mathrm{~mm}$ effective size, seem to be more effective and reliable for the turbidity removal. In another work conducted for the tertiary treatment of municipal sewage via slow sand filtration, higher removal efficiency for turbidity was reported to be about $88 \%$ for the sand with an effective size of $0.23 \mathrm{~mm}$ and a sand depth of $84 \mathrm{~cm}$ [19]. When compared with slow sand filtration $[15,19]$, the

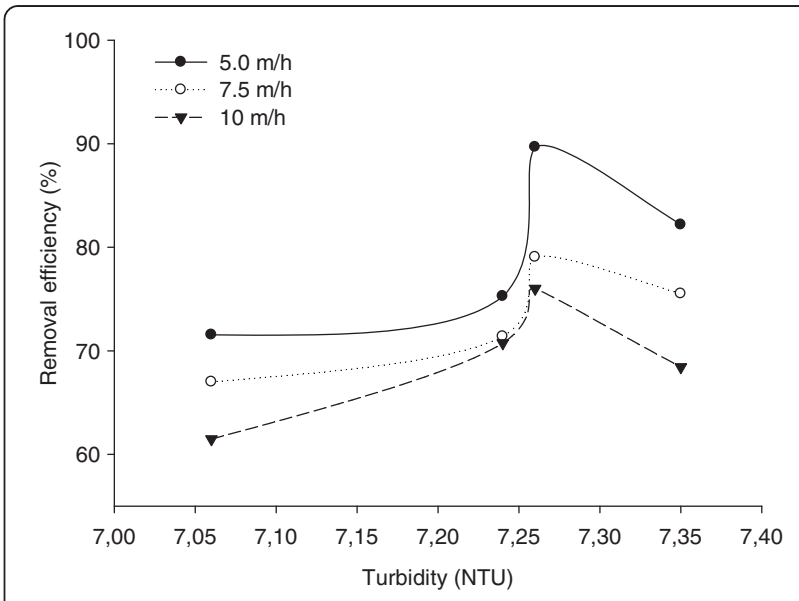

Figure 3 Removal of turbidity at various turbidity unit and surface loading rate. 
present results showed better removal percentage for turbidity. In another work for tertiary treatment of a secondary effluent by the coupling of coagulation-flocculationdisinfection, the initial turbidity was reported to be 6.9 $( \pm 4.3) \mathrm{NTU}$ and after the treatment reached to $1.2( \pm 0.4)$ NTU, which is near to the present results [15]. The overall results clearly demonstrate that only slow sand filtration is not only enough to removal of turbidity and so needs more treatment process such as coagulation or two-stage bed filtration like the present system.

\section{Removal of total phosphorous}

Phosphate exists primarily in the ionized form in the environment and naturally found in some rocks and soils. It is necessary for plant growth as a macronutrient of most of biological being and categorized as one of the main limiting nutrients of organisms living in water resource. The main role of phosphorus in environment is well known as eutrophication in surface water in its excessive limit [20].

Removal of total phosphorous (TP) by present system is shown in Figure 4. As seen from this figure, removal of phosphorous was increased with the increase in initial phosphorus concentration and reached to its maximum removal efficiency at $4.8 \mathrm{mg} / \mathrm{L}$. In addition, removal efficiency was decreased with the increase in surface loading rate and observed to be maximum at $5 \mathrm{~m} / \mathrm{h}$. At the initial phosphorus concentration of $4.80 \mathrm{mg} / \mathrm{L}$ and surface loading rate of $5 \mathrm{~m} / \mathrm{h}$, removal efficiency was observed to be about $89.1 \%$. The effluent concentration reached to about $0.52 \mathrm{mg} / \mathrm{L}$, which is lower than those reported for the phosphorous concentration (0.5-1.0 $\mathrm{mg} / \mathrm{L}$ ) for protection of the eutrophication [21].

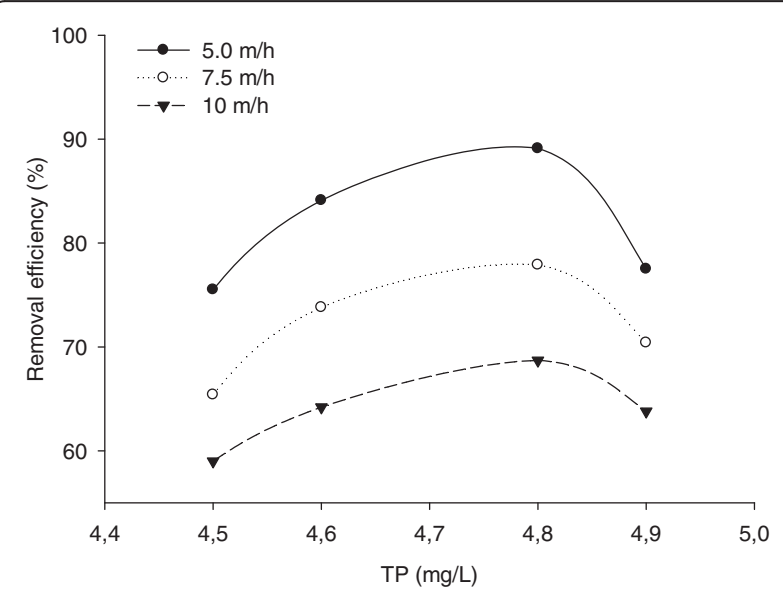

Figure 4 Removal efficiency for total phosphorous at different initial concentration and surface loading rate.

\section{Coliform removal without chlorination at different organism and hydraulic rate}

Water borne diseases are one of the main cases of human illness. Discharge of wastewater treatment plant effluents containing any type of microorganism can cause pollution of water supply resource [22]. On the other hand, improperly designed and operated water treatment plants cannot effectively remove pathogenic organisms from drinking water. This problem can result in nuisance consequences in developing counties where there is no significant water disinfection facilities [18,23,24]. World Health Organization [18] estimated that 1.1 billion people over the world cannot access to safe water. Consumption of contaminated water can cause many severe diseases such as typhoid fever, hepatitis A and E, polio and cholera [5]. Many microorganisms, especially coliform group, can cause various types of waterborne diseases. Therefore, inactivation of pathogenic organisms by appropriate methods is necessary for protection of human health from drinking of contaminated water. Originally, the chlorine and its intermediates are common chemicals that are added into the water to inactivation of pathogenic microorganisms [6,25]. Newly, many researchers indicated that addition of chlorine for disinfection of water can produce many by-products that are carcinogen for human health. Removal of these compounds by an efficient method itself is a serious subject in the field of water disinfection [7]. For that reason, any effective methods such as advanced oxidation processes $[26,27]$ that can be capable to remove pathogenic microorganisms without production of by-products would be valuable. It can be seen from the literature that, the commonly used methods for the microorganism removal are chlorination, ozonation, UV irradiation and other oxidation methods [28]. However, to the best of our knowledge, there is little work for removal of fecal and total coliform with fluidized bed accompanying with a filtration unit. For that reason, in the present work, the efficiency of FBR system with and without chlorination was also investigated for removal of total and fecal coliform organism.

Figure 5 shows the removal of total and fecal coliform without any chlorination of effluents at different microorganism concentration and surface loading rate. At the surface loading rate of $5 \mathrm{~m} / \mathrm{h}$, removal of total coliform increased as the total coliform concentration increased from $22 \times 10^{3}$ to $53 \times 10^{3}$ (MPN, Most Probable Number), and then reached to a stationary stage for increases in total coliform concentration from $53 \times 10^{3}$ to $175 \times 10^{3}$ (MPN). For the total coliform concentrations of $22 \times 10^{3}$, $46 \times 10^{3}$ and $175 \times 10^{3}(\mathrm{MPN})$, removal efficiencies were 32, 77 and $77 \%$, respectively. The effluent total coliform concentrations at those removal efficiency values were about 15,12 and $41 \times 10^{3}(\mathrm{MPN})$, respectively, which was 

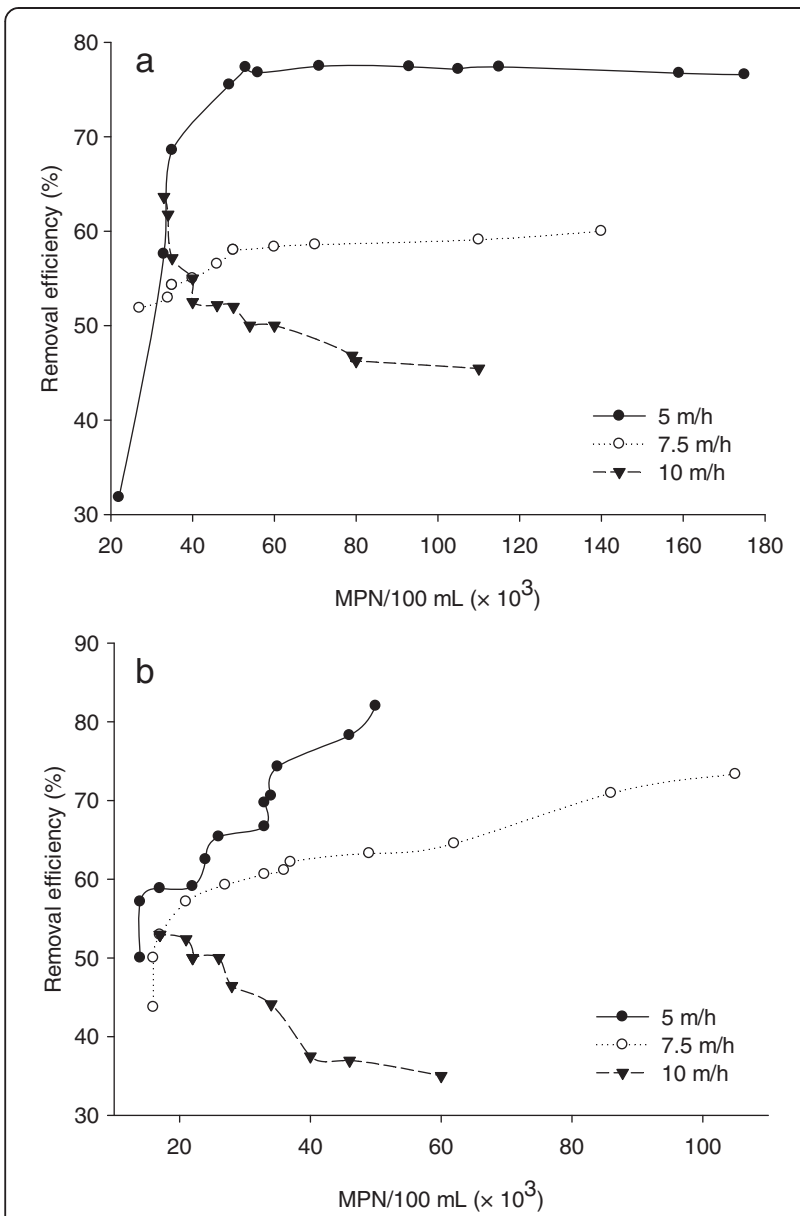

Figure 5 Removal of total coliform (a) and fecal coliform (b) at different microorganism concentration and surface loading rate without chlorination (MPN: Most Probable Number).

not acceptable for environmental discharge of effluents without chlorination. Removal of fecal coliform at $5 \mathrm{~m} / \mathrm{h}$ of surface loading rate increased about linearly with increases in fecal coliform concentration from $14 \times 10^{3}$ to $50 \times 10^{3}$ (MPN). Removal efficiencies were 50 and $82 \%$ for fecal coliform concentrations of $14 \times 10^{3}$ and $50 \times 10^{3}$ (MPN), respectively. According to these removal percentages, the effluent fecal coliform concentrations were determined as $7 \times 10^{3}$ and $9 \times 10^{3}(\mathrm{MPN})$, respectively. Results indicated that the final fecal coliform concentrations did not meet the standard levels for the fecal coliform.

At surface loading rate of $7.5 \mathrm{~m} / \mathrm{h}$, removal efficiency was increased about linearly for fecal total coliform from 52 to $60 \%$ for increases in total coliform concentration from $27 \times 10^{3}$ to $140 \times 10^{3}$ (MPN), respectively. For these values, the effluent total coliform concentrations were $13 \times 10^{3}$ to $56 \times 10^{3}(\mathrm{MPN})$, respectively. For the fecal coliform, removal efficiency increased from 44 to $73 \%$ with increases in coliform concentration from $16 \times 10^{3}$ to $105 \times 10^{3}(\mathrm{MPN})$, respectively. The effluent fecal coliform concentration was $9 \times 10^{3}(\mathrm{MPN})$ at $44 \%$ removal efficiency and $28 \times 10^{3}(\mathrm{MPN})$ at $73 \%$ removal efficiency. Result indicated that either total coliform or fecal coliform at those values of removal efficiency did not meet the standard levels for environmental discharges. Consequently, increasing of surface loading rate from 5 to 7.5 $\mathrm{m} / \mathrm{h}$ led to decreases in coliform removal efficiencies.

At surface loading rate of $10 \mathrm{~m} / \mathrm{h}$, total and fecal coliform removal efficiencies decreased with the increase in coliform concentration. With the increase in total coliform concentration from $33 \times 10^{3}$ to $110 \times 10^{3}(\mathrm{MPN})$, removal efficiency decreased from 64 to $45 \%$ respectively. On the other hand, fecal coliform removal efficiency was decreased from 53 to $35 \%$ with the increase in fecal coliform concentration from $17 \times 10^{3}$ to $60 \times 10^{3}(\mathrm{MPN})$, respectively. The concentration of total coliform in filter effluents was $12 \times 10^{3}(\mathrm{MPN})$ at $64 \%$ removal efficiency and $60 \times 10^{3}$ (MPN) at $45 \%$ removal efficiency. Similarly, fecal coliform concentration was $8 \times 10^{3}(\mathrm{MPN})$ at $53 \%$ removal efficiency and $39 \times 10^{3}(\mathrm{MPN})$ at $35 \%$ removal efficiency.
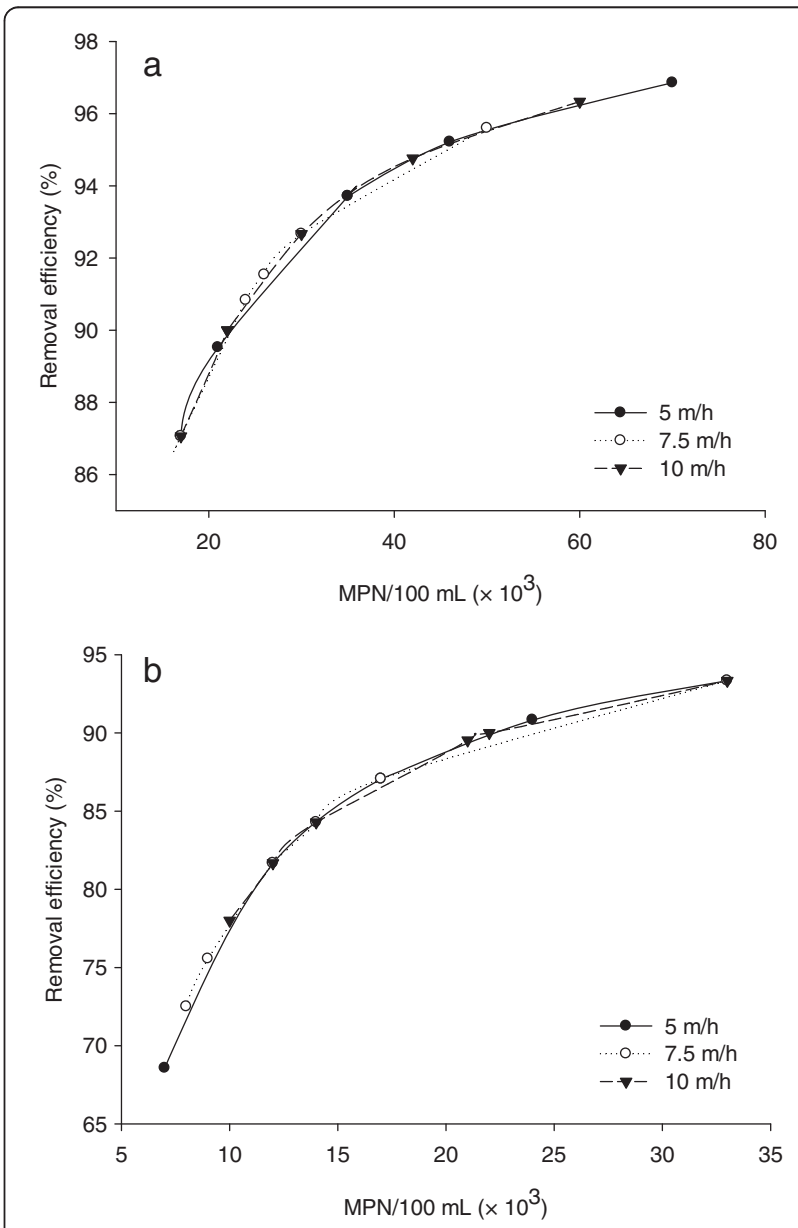

Figure 6 Removal of total coliform (a) and fecal coliform (b) at different microorganism concentration and surface loading rate with chlorination (MPN: Most Probable Number). 
Table 2 Comparison of different FBR typologies on treatment of various types of wastewaters

\begin{tabular}{|c|c|c|c|c|c|c|}
\hline Wastewater type & $\begin{array}{l}\text { Reactor type and } \\
\text { dimensions }\end{array}$ & Support material & $\begin{array}{l}\text { Initial concentrations } \\
\text { and loading rates }\end{array}$ & Operating conditions & $\begin{array}{l}\text { Efficiency } \\
\text { (i.e. } C O D, B^{\prime} D_{5}, T S \\
\text { removals, etc.) }\end{array}$ & Reference and region \\
\hline \multirow{4}{*}{$\begin{array}{l}\text { Secondary wastewater } \\
\text { treatment plant effluents }\end{array}$} & \multirow{4}{*}{$\begin{array}{l}\text { Two-stage FBR, } V=106 \mathrm{~L}, \\
\mathrm{H}=1.5 \mathrm{~m}, \mathrm{D}=0.30 \mathrm{~m}\end{array}$} & \multirow{4}{*}{$\begin{array}{l}\text { PVC material and } \\
\text { gravel }\end{array}$} & $\mathrm{COD}=32-40 \mathrm{mg} / \mathrm{L}$ & $\mathrm{pH}=7.2-7.5$ & \multirow{4}{*}{$\begin{array}{l}90.5 \%, 91 \%, 89.7 \%, 89.1 \% \\
\text { and } 98 \% \text { of COD, BOD } \\
\text { turbidity, TP and coliform } \\
\text { removals, respectively }\end{array}$} & \multirow[t]{4}{*}{ Present study, Iran } \\
\hline & & & $\mathrm{BOD}_{5}=16.9-21.5 \mathrm{mg} / \mathrm{L}$ & $\mathrm{T}=35^{\circ} \mathrm{C}$ & & \\
\hline & & & $\mathrm{TS}=556-704.6 \mathrm{mg} / \mathrm{L}$ & $v_{f}=5,7.5$ and $10 \mathrm{~m} / \mathrm{h}$ & & \\
\hline & & & Turbidity $=6.2-7.5 \mathrm{NTU}$ & & & \\
\hline \multirow[t]{4}{*}{ Synthetic starch wastewater } & \multirow{4}{*}{$\begin{array}{l}\text { Anaerobic tapered FBR, } \\
V=7.8 \mathrm{~L}\end{array}$} & \multirow{4}{*}{$\begin{array}{l}\text { Granular activated } \\
\text { carbon (GAC) }\end{array}$} & $\mathrm{OLR}=1.0-85.44 \mathrm{~kg}$ & $\mathrm{pH}=6.8-7.2$ & \multirow[t]{4}{*}{$92 \%$ of COD removal } & \multirow[t]{4}{*}{ Parthiban et al. [3], India } \\
\hline & & & & $\mathrm{HRT}=1.97-26.74 \mathrm{~h}$ & & \\
\hline & & & $\mathrm{COD}=1100-7000 \mathrm{mg} / \mathrm{L}$ & & & \\
\hline & & & $\mathrm{BOD}_{5}=690-5960 \mathrm{mg} / \mathrm{L}$ & & & \\
\hline \multirow[t]{3}{*}{ Pink water } & \multirow{3}{*}{$\begin{array}{l}\text { GAC-FBR, } H=4.9 \mathrm{~m}, \\
\mathrm{D}=0.51 \mathrm{~m}\end{array}$} & \multirow[t]{3}{*}{ GAC } & \multirow[t]{3}{*}{$\mathrm{TNT}=3.5-56.2 \mathrm{mg} / \mathrm{L}$} & $\mathrm{pH}=6.8-7$ & \multirow[t]{3}{*}{ Effluent TNT $=<0.03-2.8 \mathrm{mg} / \mathrm{L}$} & \multirow[t]{3}{*}{ Maloney et al. [30], USA } \\
\hline & & & & $\mathrm{HRT}=125-375 \mathrm{~min}$ & & \\
\hline & & & & $\mathrm{T}=67-106.5^{\circ} \mathrm{F}$ & & \\
\hline \multirow[t]{3}{*}{ Real textile wastewater } & \multirow{3}{*}{$\begin{array}{l}\text { Anaerobic FBR, V = } 4 \mathrm{~L} \\
\mathrm{H}=73 \mathrm{~cm}, \mathrm{D}=5.2 \mathrm{~cm}\end{array}$} & \multirow[t]{3}{*}{ Pumice } & \multirow{3}{*}{$\begin{array}{l}\mathrm{OLR}=1-5 \mathrm{~kg} C O D /\left(\mathrm{m}^{3} . \mathrm{day}\right) \\
\mathrm{COD}=1030-6000 \mathrm{mg} / \mathrm{L}\end{array}$} & $\mathrm{HRT}=24 \mathrm{~h}$ & \multirow{3}{*}{$\begin{array}{l}82 \%, 94 \% \text { and } 59 \% \text { of } \mathrm{COD}, \mathrm{BOD}_{5} \\
\text { and color removals, respectively }\end{array}$} & \multirow{3}{*}{$\begin{array}{l}\text { Sen and Demirer [31], } \\
\text { Turkey }\end{array}$} \\
\hline & & & & $\mathrm{T}=35( \pm 2)^{\circ} \mathrm{C}$ & & \\
\hline & & & & $v_{f}=19 \mathrm{~m} / \mathrm{h}$ & & \\
\hline \multirow{4}{*}{$\begin{array}{l}\text { Diesel fuel (DF)-contaminated } \\
\text { wastewater }\end{array}$} & \multirow{4}{*}{$\begin{array}{l}\text { Three-phase FBR, } V=200 \mathrm{~L}, \\
\mathrm{H}=3 \mathrm{~m}, \mathrm{D}=0.17 \mathrm{~m}\end{array}$} & \multirow[t]{4}{*}{ Lava rock particles } & \multirow{4}{*}{$\begin{array}{l}\mathrm{DF}=50-700 \mathrm{mg} / \mathrm{L} \\
\mathrm{COD}=547-4025 \mathrm{mg} / \mathrm{L}\end{array}$} & $\mathrm{pH}=6.7-7.8$ & \multirow{4}{*}{$\begin{array}{l}>99.9 \%, 96.2 \%, 99.9 \% \text { and } 47.8 \% \\
\text { of DF, COD, TS and turbidity } \\
\text { removals, respectively }\end{array}$} & \multirow[t]{4}{*}{ Lohi et al. [32], Canada } \\
\hline & & & & $\mathrm{HRT}=4 \mathrm{~h}$ & & \\
\hline & & & & $\mathrm{T}=20( \pm 5)^{\circ} \mathrm{C}$ & & \\
\hline & & & & $v_{f}=0.3 \mathrm{~cm} / \mathrm{s}$ & & \\
\hline \multirow[t]{3}{*}{ Brewery wastewater } & \multirow{3}{*}{$\begin{array}{l}\text { Anaerobic inverse } F B R \\
V=1.9 \mathrm{~L}, \mathrm{H}=1.37 \mathrm{~m} \\
\mathrm{D}=4.48 \mathrm{~cm}\end{array}$} & Small silica & & $\mathrm{pH}=7$ & \multirow[t]{3}{*}{$>90 \%$ of COD removal } & \multirow{3}{*}{$\begin{array}{l}\text { Alvarado-Lassman et al. } \\
\text { [33], Mexico }\end{array}$} \\
\hline & & \multirow{2}{*}{$\begin{array}{l}\text { particles and } \\
\text { polyethylene } \\
\text { material }\end{array}$} & $\mathrm{OLR}=70 \mathrm{~kg} \mathrm{COD} /\left(\mathrm{m}^{3}\right.$. day $)$ & $\mathrm{T}=35^{\circ} \mathrm{C}$ & & \\
\hline & & & $\mathrm{BOD}_{5}=1375 \mathrm{mg} / \mathrm{L}$ & $v_{f}=6 \mathrm{~m} / \mathrm{h}$ & & \\
\hline Textile wastewater & Anaerobic FBR, $V=3.75 \mathrm{~L}$, & Activated carbon & $\mathrm{OLR}=1.5-8.4 \mathrm{~kg} \mathrm{COD} /\left(\mathrm{m}^{3}\right.$. day $)$ & $\mathrm{pH}=7.8$ & $98 \%, 95 \%$ and $65 \%$ of $C O D, B^{-} D_{5}$ & Haroun and Idris [34], \\
\hline & $\mathrm{H}=750 \mathrm{~mm}, \mathrm{D}=8$ & & COD & $\mathrm{HRT}=4-12 \mathrm{~h} \mathrm{~T}=35^{\circ} \mathrm{C}$ & & \\
\hline High-strength distillery & Anaerobic FBR, V = 5.9 L, & Natural zeolite & $\mathrm{OLR}=3-20 \mathrm{~kg} C O D /\left(\mathrm{m}^{3}\right.$. day $)$ & $\mathrm{pH}=6.7-7.6$ & $>80 \%$ of COD removal & Fernandez et al. [35], \\
\hline & $\mathrm{H}=74 \mathrm{~cm}, \mathrm{D}=6.5 \mathrm{~cm}$ & & & $\mathrm{~T}=30( \pm 2)^{\circ} \mathrm{C}$ & & \\
\hline
\end{tabular}


Results demonstrated that total and fecal coliform could be removed effectively in surface loading rate of 5 and $7.5 \mathrm{~m} / \mathrm{h}$, with increasing in organism concentration. Decreases in coliform removal efficiency at $10 \mathrm{~m} / \mathrm{h}$ surface rate may be attributed to the removal of biofilm layer from the fluidized bed and also due to disorienting of the filter bed at high hydraulic loading conditions. Therefore, it can be concluded that both surface rate and microorganism concentration will affect the removal efficiency. In overall, the microorganism concentration as coliform from wastewater plant effluent and influent to the FBR system was in the range of $15-175 \times 10^{3}$ (MPN), and the present system removed about $30 \%$ to $83 \%$ of microorganism depending on the microorganism type and the surface loading rate. However, it is noted that the discharge standard for secondary wastewater as coliform organism has been reported to be below 200$400 \mathrm{MPN} / 100 \mathrm{~mL}$ [28]. The removal percentage of present system was considerable, but the FBR could not meet the compliance with the effluent discharge standards for the coliform organism without chlorination. Therefore, a proper disinfection will be required when treating secondary wastewater with the FBR system.

\section{Coliform removal with chlorination}

Figure 6 shows the effect of chlorine addition on coliform organism removal efficiency in used reactor. As seen from this figure, addition of chlorine leads to increase in microorganism removal without affected by hydraulic loading rate. With chlorination, almost 90 to $98 \%$ of both total and fecal coliform were removed depending on coliform concentration and hydraulic surface loading rate. Considering all applied surface loading rates and different microorganism concentrations, the final concentrations for both total and fecal coliform were reached to below $2.2 \mathrm{MPN} / 100 \mathrm{~mL}$. Therefore, it can be concluded that the FBR system can meet the water standard for drinking water with chlorine addition [13]. It is reported that chlorine concentration for the oxidation of raw or secondary wastewater can be as high as $5-20 \mathrm{mg} / \mathrm{L}$ and at such higher level; chlorine addition leads to enhance TS concentration in the treated wastewater [28]. However, in the present work, we observed no increment in TS concentration during FBR-chlorination of secondary wastewater for the removal of coliform organism. More importantly, the used chlorine concentration $(1 \mathrm{mg} / \mathrm{L})$ applied to the secondary wastewater was very low as compared to other studies, indicating the advantage of the present system for the microorganism removal.

Table 2 summarizes performance data concerning the comparison of different FBR configurations on treatment of various types of wastewaters such as synthetic starch wastewater [29], pink water [30], real textile wastewater
[31], diesel fuel-contaminated wastewater [32], brewery wastewater [33], textile wastewater [34], and highstrength distillery wastewater [35]. The performance data reveals that wide range of operating conditions have been conducted to remove $\mathrm{COD}, \mathrm{BOD}_{5}$, color, TS, TP and others. Various types of materials such as PVC, gravel, granular activated carbon (GAC), pumice, lava rock particles, small silica particles, polyethylene material and natural zeolite, has been used as growth support media. The performance data figures out that initial $\mathrm{pH}$ has been conducted between 6.7 and 7.8, and a wide range of initial COD has been studied in the limits of $32-7000 \mathrm{mg} / \mathrm{L}$. On the basis of maximum removals obtained from different FBR configurations, the present data seems to be comparable with those reported by others (Table 2). However, it is noted that differences are due to the characteristics of studied wastewaters and experimental conditions such as applied loading rates, initial concentration of pollutants, hydraulic retention time, operating temperature, and also different types of support media. These differences may also be attributed to the presence of several recalcitrant inorganic compounds, complex components, and other undesirable impurities in the wastewaters.

As seen from the recent literature, there are no systematic papers specifically devoted to a study regarding the application of a two-stage FBR system with a filtration column for the post-treatment treatment of secondary wastewater treatment plant effluents. For this reason, the present study aimed at fulfilling the gap in this field by focusing upon the treatment performance of FBR technology on real secondary effluents. Moreover, most of studies were conducted at laboratory-scale; however, the applicability of the FBR system was specifically investigated at pilot-scale in the present work. Besides conventional waster parameters, the efficiency of a twostage FBR system was also investigated as a specific objective for inactivation of pathogenic organisms (i.e. total and fecal coliform organism) with and without chlorination. Based on the above-mentioned facts, the novelty of the present study is highlighted with comparison of experimental results from the previous publications.

\section{Conclusion}

The study revealed that a two-stage pilot-scale FBR system for secondary wastewater treatment was technically feasible in terms of $\mathrm{BOD}_{5}$, COD, turbidity, TP, total coliform and fecal coliform. Depending on both microorganism concentration and applied surface loading rates, the FBR system could meet the available standards with removal percentages above $90 \%$. The FBR-chlorination system could be used as a promising post-treatment process to improve the quality of the final discharge without any increase in TS concentration during the chlorination. 


\section{Competing interests}

The authors declare that they have no competing interests.

\section{Authors' contributions}

GHS was involved in experimental parts and take the initial samples from wastewater treatment plant. KY was involved in drafting the manuscript or revising it critically for important intellectual content, and made substantial contributions to conception and design. AHM reviewed the final manuscript and also involved in experimental parts. MZ participated in the design of the study, made substantial contributions to acquisition of data, or analysis and interpretation of data, and gave final approval of the version to be published. All authors read and approved the final manuscript.

\section{Acknowledgements}

The authors would like to thank the Alborz University of Medical Sciences for supporting of this work.

\section{Author details}

${ }^{1}$ Department of Environmental Health Engineering, School of Public Health, Tehran University of Medical Sciences, Tehran, Iran. ${ }^{2}$ Department of Environmental Engineering, Faculty of Civil Engineering, Yildiz Technical University, Istanbul, Turkey. ${ }^{3}$ Department of Environmental Health Engineering \& Center of Water Quality Research, Tehran University of Medical Sciences, Tehran, Iran. ${ }^{4}$ Department of Environmental Health Engineering, Faculty of Health, Alborz University of Medical Sciences, Karaj, Iran.

Received: 17 December 2012 Accepted: 9 June 2013

Published: 17 June 2013

\section{References}

1. Zhang W, Xie Q, Rouse JD, Qiao S, Furukawa K: Treatment of high-strength corn steep liquor using cultivated polyvinyl alcohol gel beads in an anaerobic fluidized-bed reactor. J Biosci Bioeng 2009, 107(1):49-53.

2. Sowmeyan $R$, Swaminathan $G$ : Evaluation of inverse anaerobic fluidized bed reactor for treating high strength organic wastewater. Biores Technol 2008, 99(9):3877-3880.

3. Parthiban $R$, lyer $P$, Sekaran $G$ : Anaerobic tapered fluidized bed reactor for starch wastewater treatment and modeling using multilayer perceptron neural network. J Environ Sci 2007, 19(12):1416-1423.

4. Chao-Hai W, Wen-Xiang W, Zhi-Yi D, Chao-Fei W: Characteristics of highsulfate wastewater treatment by two-phase anaerobic digestion process with Jet-loop anaerobic fluidized bed. J Environ Sci 2007, 19(3):264-270.

5. Seven O, Dindar B, Aydemir S, Metin D, Ozinel MA, Icli S: Solar photocatalytic disinfection of a group of bacteria and fungi aqueous suspensions with $\mathrm{TiO}_{2}, \mathrm{ZnO}$ and Sahara desert dust. J Photochem Photobio A Chem 2004, 165(1-3):103-107.

6. Yin YG, Ding Y: A close to real-time prediction method of total coliform bacteria in foods based on image identification technology and artificial neural network. Food Res Inter 2009, 42(1):191-199.

7. Andreozzi R, Caprio V, Insola A, Marotta R: Advanced oxidation processes (AOP) for water purification and recovery. Catalysis Today 1999, 53(1):51-59.

8. Lonnen J, Kilvington S, Kehoe SC, Al-Touati A, McGuigan KG: Solar and photocatalytic disinfection of protozoan, fungal and bacterial microbes in drinking water. Water Res 2005, 39(5):877-883.

9. AWWA (American Water Work Accocation): Standard methods for the examination of water and wastewater. 21st edition. Washington DC: AWWA; 2005.

10. $\mathrm{Ngo} \mathrm{HH}$, Vigneswaran S: Application of floating medium filter in water and wastewater treatment with contact-flocculation filtration arrangement. Water Res 1995, 29(9):2211-2213.

11. Ngo HH, Vigneswaran S: Application of down flow floating medium flocculator/prefilter (DFF) - coarse sand filter (CSF) in nutrient removal. Water Sci Technol 1996, 33(3):63-70.

12. Davidson J, Helwig N, Summerfelt ST: Fluidized sand biofilters used to remove ammonia, biochemical oxygen demand, total coliform bacteria, and suspended solids from an intensive aquaculture effluent. Aqua Eng 2008, 39(1):6-15.

13. World Health Organization (WHO): Guidelines for the safe use of wastewater excreta and grey water, printed in France. 2006.

14. United Nations Environment Programme (UNEP) World Health Organization (Ed): Water Quality Monitoring. Firstth edition. London, UK: Published by E\&FN Spon; 1996.
15. Ustun GE, Akal Solmaz SK, Ciner F, Baskaya HS: Tertiary treatment of a secondary effluent by the coupling of coagulation-flocculationdisinfection for irrigation reuse. Desalination 2011, 277(1-3):207-212.

16. Tyagi VK, Khan AA, Kazmi AA, Mehrotra I, Chopra AK: Slow sand filtration of UASB reactor effluent: A promising post treatment technique. Desalination 2009, 249(2):571-576.

17. Fallmann H, Krutzler T, Bauer R, Malato S, Blanco J: Applicability of the Photo-Fenton method for treating water containing pesticides. Catalysis Today 1999, 54(2-3):309-319.

18. World Health Organization (WHO): Guidelines for Drinking-water Quality, Volume 1. 3rd edition. Geneva: Recommendation; 2004

19. Al-Adham SS: Tertiary treatment of municipal sewage via slow sand filtration, MS Thesis. Dhahran, Saudi Arabia: King Fahd University of Petroleum \& Minerals; 1989

20. Tunali Akar S, Tosun I, Ozcan A, Gedikbey T: Phosphate removal potential of the adsorbent material prepared from thermal decomposition of alunite ore- $\mathrm{KCl}$ mixture in environmental cleanup. Desalination 2010, 260(1-3):107-113.

21. Zhang J, Shen Z, Shan W, Chen Z, Mei Z, Lei Y, Wang W: Adsorption behavior of phosphate on Lanthanum(III) doped mesoporous silicates material. J Env Sci 2010, 22(4):507-511.

22. Hwang MG, Katayama H, Ohgaki S: Inactivation of Legionella pneumophila and Pseudomonas aeruginosa: Evaluation of the bactericidal ability of silver cations. Water Res 2007, 41(18):4097-4104.

23. Ausland G, Stevik TK, Hanssen JF, Kohler JC, Jenssen PD: Intermittent filtration of wastewater-removal of fecal coliforms and fecal streptococci. Water Res 2002, 36(14):3507-3516.

24. Oates PM, Shanahan P, Polz MF: Solar disinfection (SODIS): simulation of solar radiation for global assessment and application for point-of-use water treatment in Haiti. Water Res 2003, 37(1):47-54.

25. Melian JAH, Rodroguez JMD, Suarez AV, Rendon ET, Do Campo CV, Arana J, Pena JP: The photocatalytic disinfection of urban wastewaters. Chemosphere 2000, 41(3):323-327.

26. Alrousan DMA, Dunlop PSM, McMurray TA, Byrne JA: Photocatalytic inactivation of E. coli in surface water using immobilised nanoparticle $\mathrm{TiO}_{2}$ films. Water Res 2009, 43(1):47-54.

27. Lydakis-Simantiris N, Riga D, Katsivela E, Mantzavinos D, Xekoukoulotakis NP. Disinfection of spring water and secondary treated municipal wastewater by $\mathrm{TiO}_{2}$ photocatalysis. Desalination 2010, 250(1):351-355.

28. Metcalf and Eddy: Wastewater Engineering, Treatment and Reuse. 4th edition. Singapore: Mc Graw Hill; 2005.

29. Rangasamy P, Pvr I, Ganesan S: Anaerobic tapered fluidized bed reactor for starch wastewater treatment and modeling using multilayer perceptron neural network. J Environ Sci 2007, 19(12):1416-1423.

30. Maloney SW, Adrian NR, Hickey RF, Heine RL: Anaerobic treatment of pinkwater in a fluidized bed reactor containing GAC. J Hazard Mater 2002, 92(1):77-88.

31. Sen S, Demirer GN: Anaerobic treatment of real textile wastewater with a fluidized bed reactor. Water Res 2003, 37(8):1868-1878.

32. Lohi A, Alvarez Cuenca M, Anania G, Upreti SR, Wan L: Biodegradation of diesel fuel-contaminated wastewater using a three-phase fluidized bed reactor. J Hazard Mater 2008, 154(1-3):105-111.

33. Alvarado-Lassman A, Rustrian E, García-Alvarado MA, Rodríguez-Jiménez GC, Houbron E: Brewery wastewater treatment using anaerobic inverse fluidized bed reactors. Biores Technol 2008, 99(8):3009-3015.

34. Haroun $M$, Idris $A$ : Treatment of textile wastewater with an anaerobic fluidized bed reactor. Desalination 2009, 237(1-3):357-366.

35. Fernandez N, Montalvo S, Borja R, Guerrero L, Sanchez E, Cortes I, Colmenarejo MF, Travieso L, Raposo F: Performance evaluation of an anaerobic fluidized bed reactor with natural zeolite as support material when treating high-strength distillery wastewater. Renew Energ 2008, 33(11):2458-2466.

doi:10.1186/2052-336X-11-10

Cite this article as: Safari et al:: Post-treatment of secondary wastewater treatment plant effluent using a two-stage fluidized bed bioreactor system. Journal of Environmental Health Science and Engineering 2013 $11: 10$ 